Maja Trstenjak $\bowtie$

Tihomir Opetuk

https://doi.org/10.21278/TOF.44301

ISSN 1333-1124

eISSN 1849-1391

\title{
INDUSTRY 4.0 READINESS FACTOR CALCULATION AND PROCESS PLANNING: STATE-OF-THE-ART REVIEW
}

\begin{abstract}
Summary
Process planning is confronting changes in terms of Industry 4.0. If the strategy and the investment plan are not defined properly, changes might cause loss. This emphasizes the importance of the readiness factor calculation. The factor expresses the current stage of development and enables the definition of a plan of action with respect to a goal. This paper gives a state-of-the-art preview of existing readiness factor calculation methods both within scientific and commercial approaches. Relation between the Industry 4.0, process planning and readiness factor calculation methods is examined and the scientific gap in the field is detected. This has enabled to create a framework of the new readiness factor calculation method, specialized for process planning in Industry 4.0.
\end{abstract}

Key words: $\quad$ process planning, industry 4.0, readiness factor, smart factory

\section{Introduction}

Industry 4.0, as a future concept that should be the main goal of every company, requires more or less radical changes, depending on the industry type and its current unique characteristics. The change is really needed, because as the time passes by and the technology gains availability on the market, the leading players on the market will accept the digital concept of modularity and flexibility as the main characteristics, while others will be left behind [1]. This will only increase the gap between the leading position and others, which will especially affect small and medium-sized enterprises (SMEs), which will not be ready to change [2]. The new digital concept not only enables the real-time data collection, but also advances the future strategic moves with the help of techniques of predictive analytics.

The implementation of the new digital concept deals with the challenges of risk management as an important issue to be resolved [3], and with other obstacles such as the human resistance to change the present because their working environment will be different. So, not only that the physical transformation is in progress, but it also affects the human tasks and skills required; this creates the need for a special overview of human skills and motivation [4].

The customized product, as the final result, created in accordance with high quality requirements and at optimized expenses within the manufacturing process and with a short time-to-market, is another big advantage. This, however, requires us to reinforce the market trends that encourage the production of customized, unique products for every client. Process 
planning is a very important part of the manufacturing process, in which the required technologies for production are defined, alongside with the work regimes, tools, machines, and operation sequencing [5]. When it comes to flexible and customized manufacturing, the Industry 4.0 concept requires that the process plans have to be defined more often than in the traditional manufacturing approach in which products are less variable and less often customized for the single user. This increases the possibility of error, of un-optimized process plan, which results in an increase in costs and a decrease in the product quality. As time-tomarket has to be as short as possible, the process plan has to be generated as quickly as possible, even automatically and digitally with the help of artificial intelligence or advanced mathematical methods.

Traditional process planning is mostly based on the subjective knowledge of a single person and is done completely by humans. The first step in the process planning digitalization is the implementation of CAM systems, which enables the production simulation and computer-generated work regimes. The next step is the implementation of computer-aided process planning (CAPP), which is a connection between design, process planning, and manufacturing, and the highest level, by the paradigm of Industry 4.0 concept, is a completely digital and personalized system which collects data from the entire supply chain and enables the process planner to use it in order to create the optimum process plan [6]. It also enables the automatized definition of process plan for different variances of the customized products. Realtime data manipulation is linked to the scheduling process, in which the manufacturing process defined can result in a high quality product at lower costs and in the shortest possible time.

The same as in every other part of the supply chain and company organization in general, Industry 4.0 requires changes in the field of process planning, but before the implementation of the new digital concept, the readiness factor should be calculated. It defines the current level of Industry 4.0 maturity or the state of the process planning method used in the company in general, and evaluates the gap between the current state and the ideal state according to the Industry 4.0 concept. Since the transformation requires a relatively high level of investment, which may be an impossible goal to achieve, especially for SMEs, the accurate readiness factor calculation is essential for the further definition of strategic and investment plans.

The importance of transformation in this field is directly linked to the successful transformation of other parts of the value chain and the whole system in general. That is why in the following chapters the current scientific contributions in the field of readiness factor for process planning will be studied, including the detection of the gap. A new framework will be proposed based on the obtained results.

\section{Methodology}

Industry 4.0, the term and the concept, was presented at the Hannover Fair in 2011. That is why the data for this research are collected in the period from 2011 to $2019^{1}$. The papers published in the two biggest and most relevant scientific databases will be reviewed (WoS and Scopus). The examined topics are connected to Industry 4.0 and its key dimensions such as Smart Factory, Internet of Things, Cyber Physical Systems, Process Planning, and Readiness Factor. Industry 4.0 is a term that represents a digital factory and the strategy for the industrial digitization, recognizable in Europe. Smart Factory is a digital transformation of the current factory, its digital version and a future target, according to the Industry 4.0

\footnotetext{
${ }^{1}$ Data published by 30 November 2019
} 
concept. Internet of Things is a system of interrelated computing devices, mechanical and digital machines with the ability to transfer data over a network. Therefore, it is an essential part of the Smart Factory and Industry 4.0, and is also very closely related to them. Cyber Physical Systems is a system in which a mechanism is controlled or monitored by computerbased algorithms. It is very similar to the Internet of Things, which it shares the same basic architecture with, but represents a higher combination of and a coordination between physical and computational elements [7]. The overlap between these terms will later be reviewed in detail, to recognize the scientific gap which is still present.

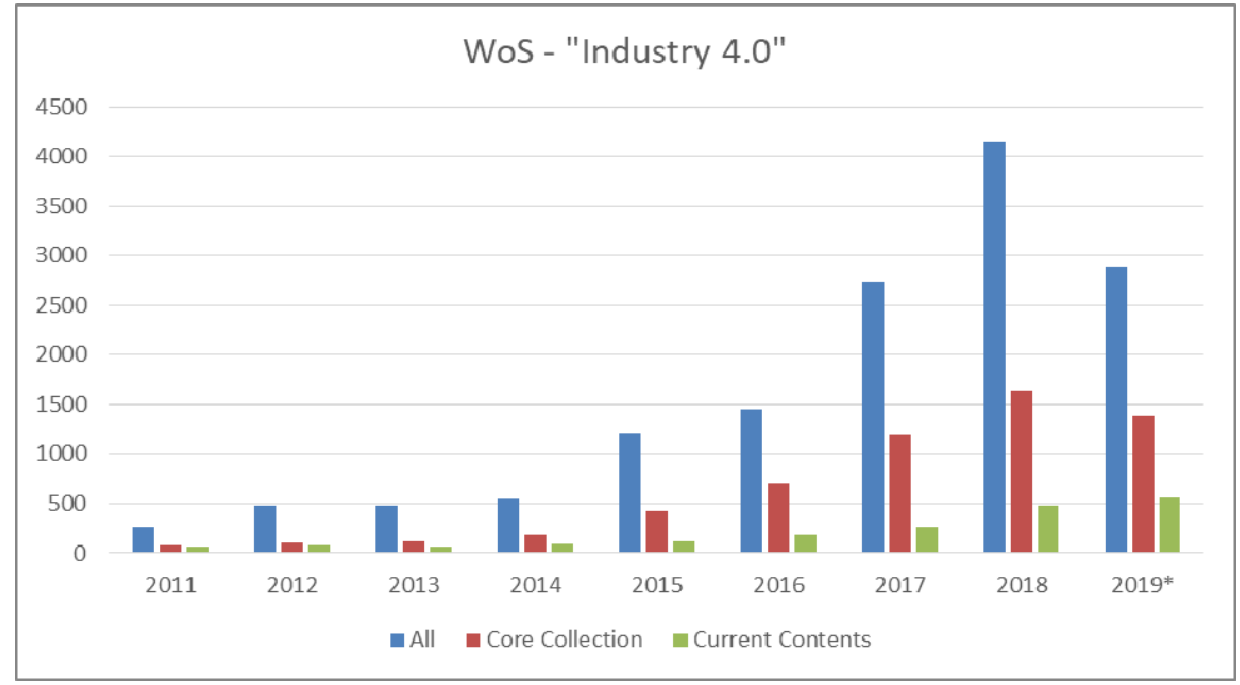

Fig. 1 Papers published from 2011 to2019 in the Web of Science database related to the Industry 4.0 topic

Based on the data collected from the Web of Science $(W o S)$ database (All) and its subcategories (Core Collection and Current Contents), which acknowledge the increased scientific significance of papers published, it has been noticed that the Industry 4.0 topic achieved ever-increasing popularity in the scientific research over the researched period of time. The sharpest increase occurred in 2018, which is recognized as the peak. In 2019, a slight decrease in the number of research papers on the Industry 4.0 topic was noticed, while the number of papers published in the Current Contents Connect database keeps growing.

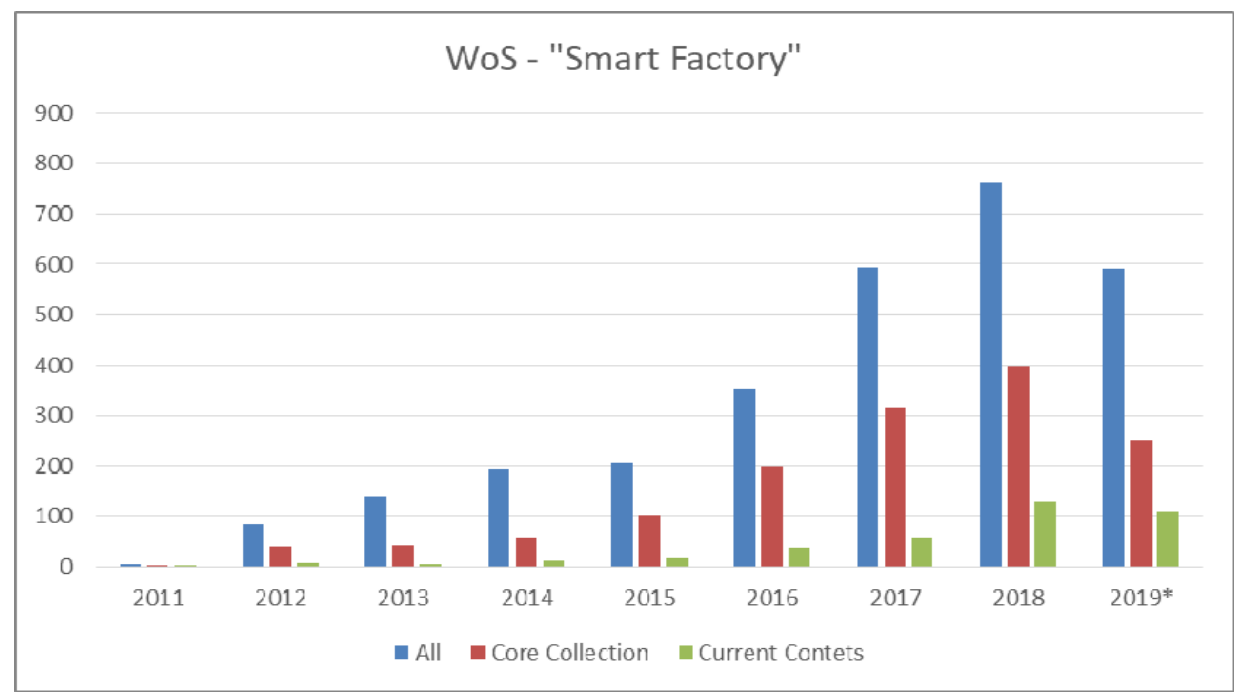

Fig. 2 Papers published from 2011 to 2019 in the Web of Science database related to the Smart Factory topic 


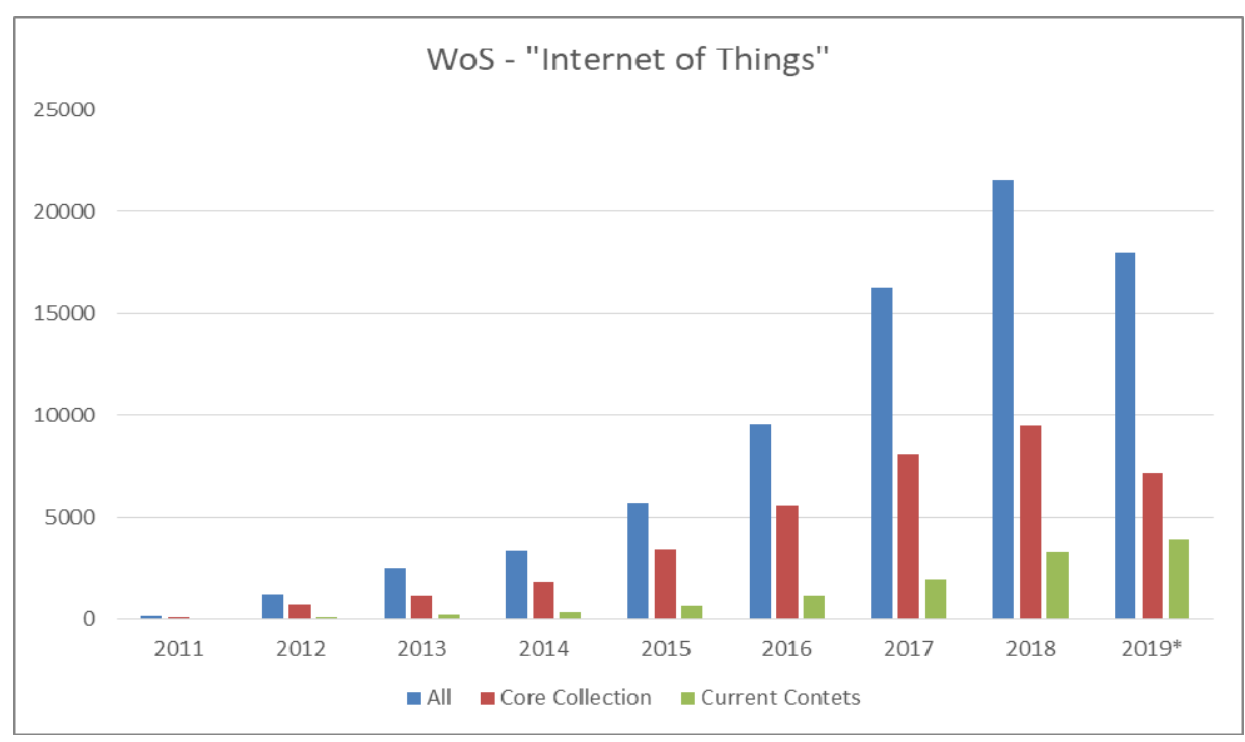

Fig. 3 Papers published from 2011 to2019 in the Web of Science database related to the Internet of Things topic

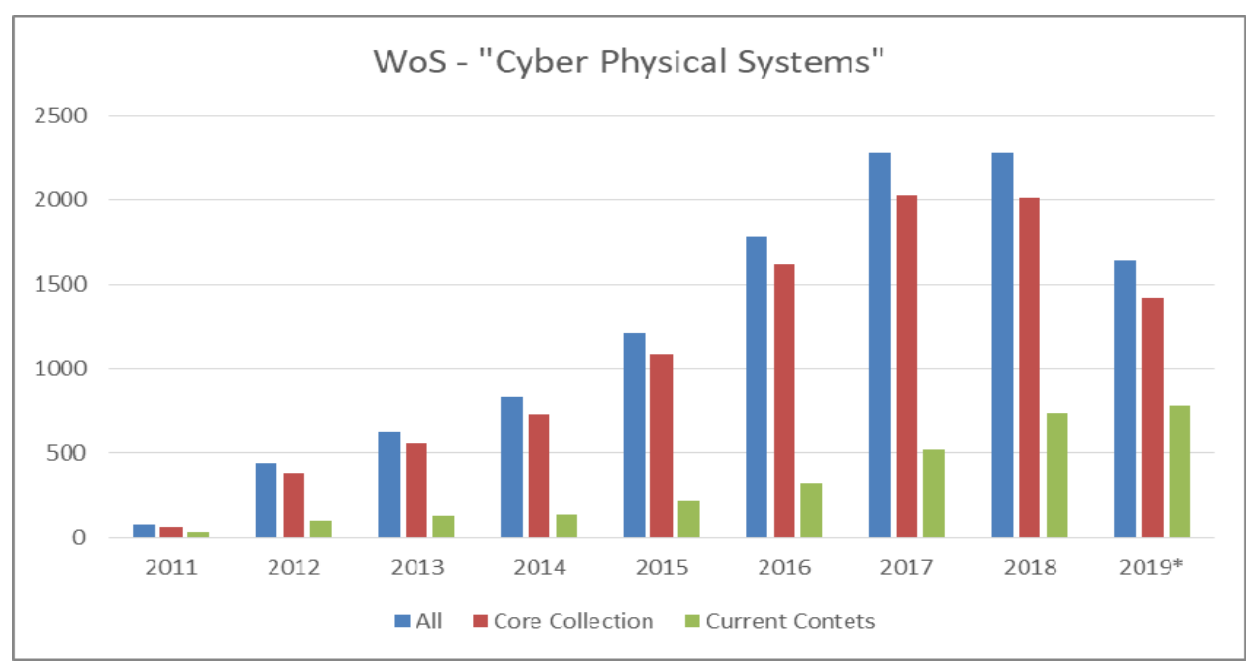

Fig. 4 Papers published from 2011 to2019 in the Web of Science database related to the Cyber Physical Systems topic

The same research has been conducted with the terms connected to the Industry 4.0 topic, which are Smart Factory, Internet of Things, and Cyber Physical Systems. The same statistical path has been noticed, with the peak of published papers in 2018, followed by a slight decrease in 2019. The decrease could be also accounted for by the fact that the data collected in 2019 are limited to the January-November period. But within all topics, a modest growth within the Current Contents Connect database has been noticed, which is where the most relevant papers from the field are published. 


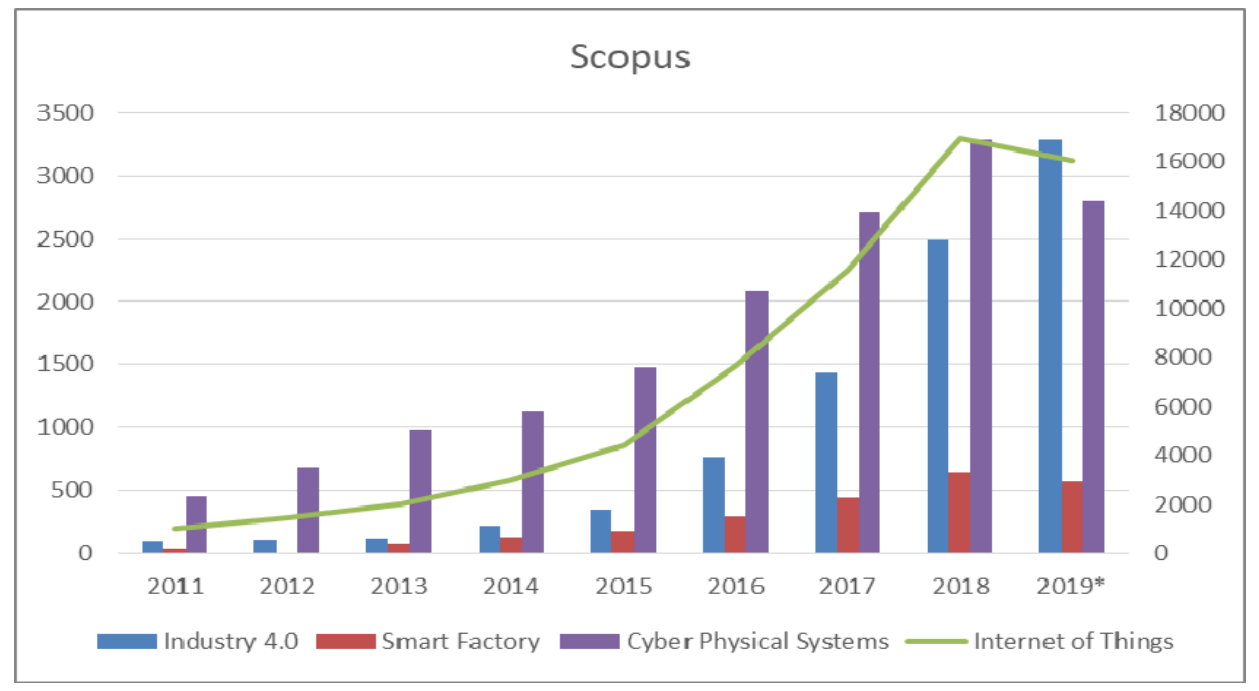

Fig. 5 Papers published from 2011 to 2019 in the Scopus database related to the Industry 4.0, Smart Factory, Cyber Physical Systems, and Internet of Things topics

In the Scopus database, there is no decrease in the popularity of Industry 4.0 as a topic. The growth over the years is noticed, with the peak in 2019. On the other hand, there is a slight decrease in the number of papers published on the topics of Internet of things, Smart Factory, and Cyber Physical Systems, but the decrease is not considered as significant in general.

Process planning as a term covers an exceptionally wide field of scientific interest, and it has been the topic of research for the past few decades. Although there are many subtopics of this field, a slight increase in the number of papers published in this field has been noticed over the years, with the peak in 2018 and a decrease in 2019 - both in the WoS and Scopus databases.

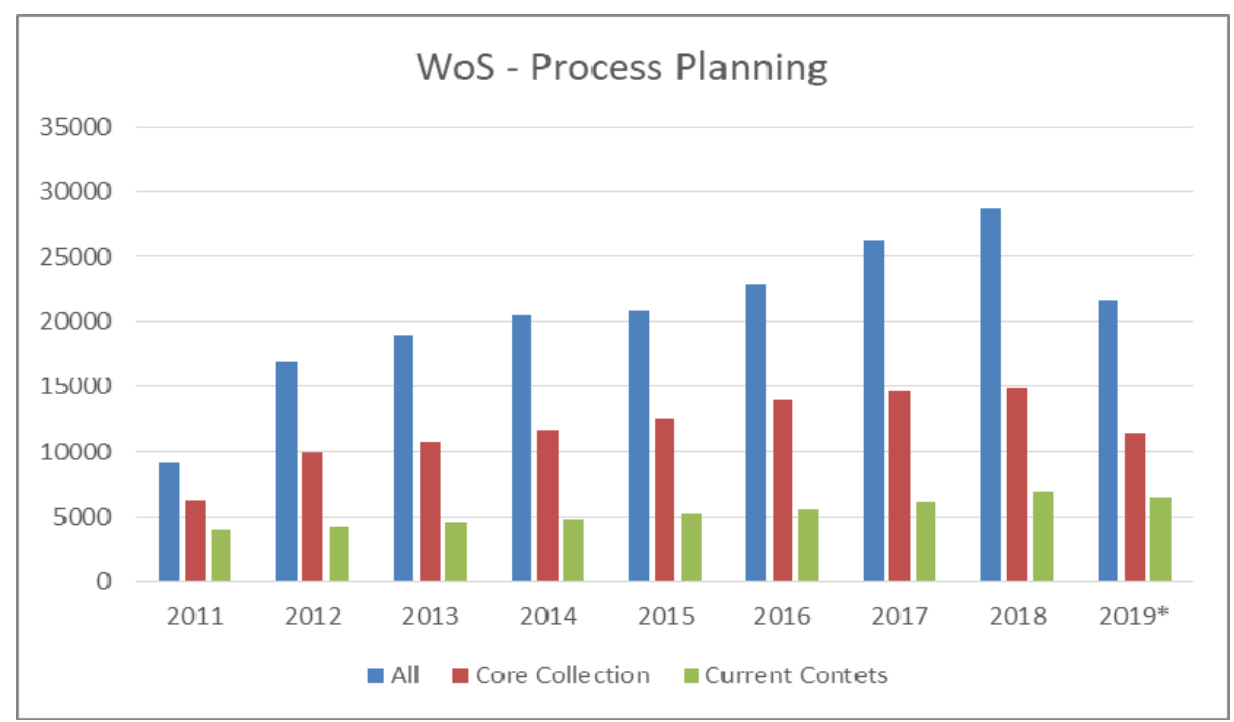

Fig. 6 Papers published from 2011 to2019 in the Web of Science database related to the Process Planning topic 


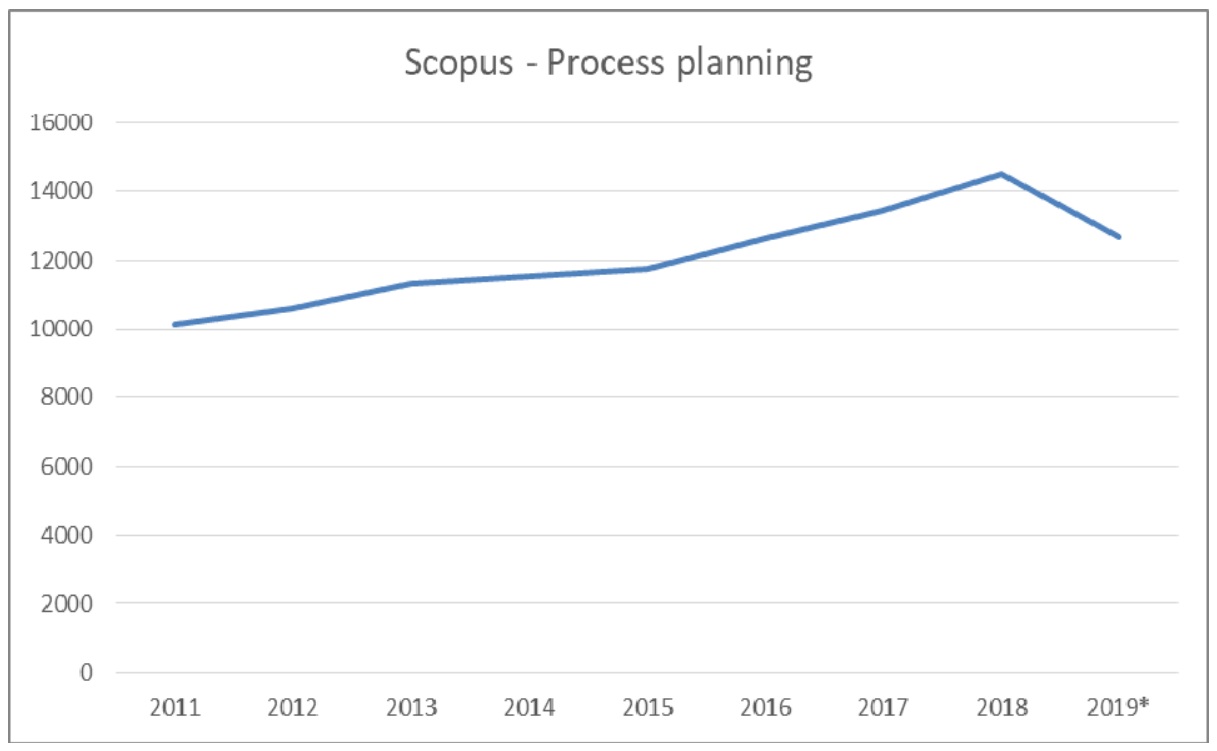

Fig. 7 Papers published from 2011 to 2019 in the Scopus database related to the Process Planning topic

The next step is to explore the overlaps between these two fields - Industry 4.0 and Process Planning. The results are shown below.

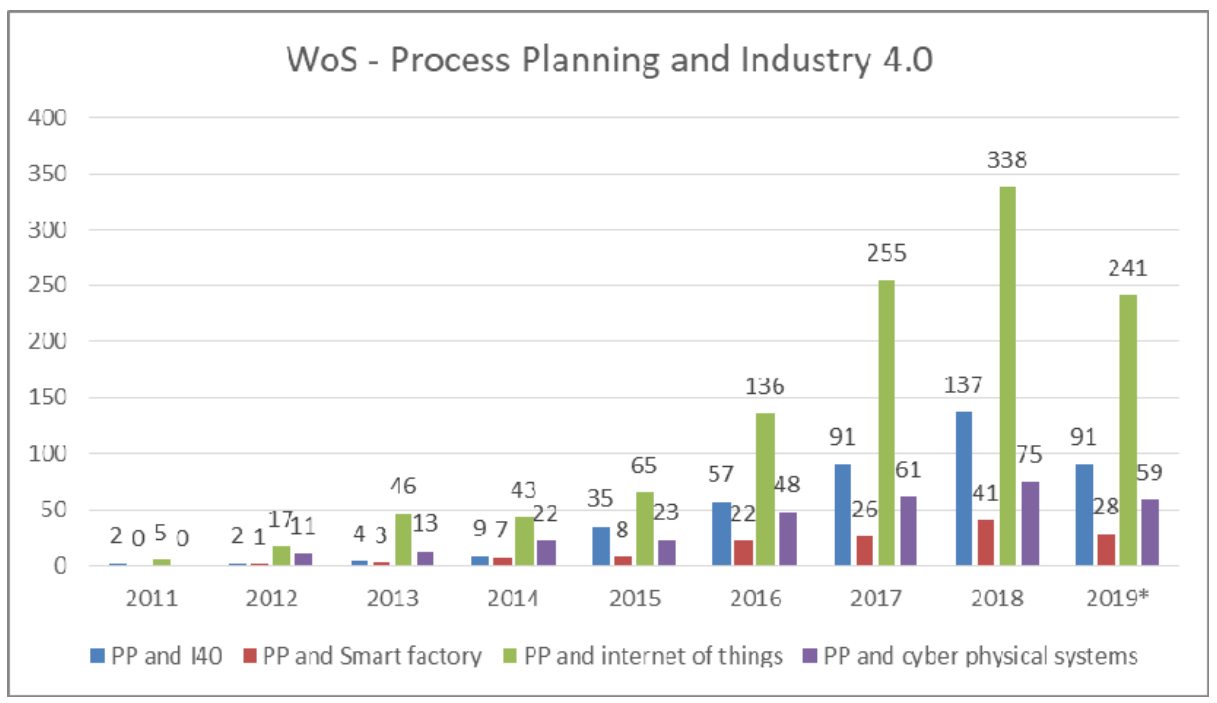

Fig. 8 Papers published from 2011 to 2019 in the Web of Science database related to the Process Planning topic and Industry 4.0 and the related terms

Once again, a similar trend of the peak in 2018 can be noticed, but in the total number of papers published on this topic, only about $1-5 \%$ papers on the Industry 4.0 topic deal with the field of process planning, its structure and implementation in the new digital factory concept and environment. 


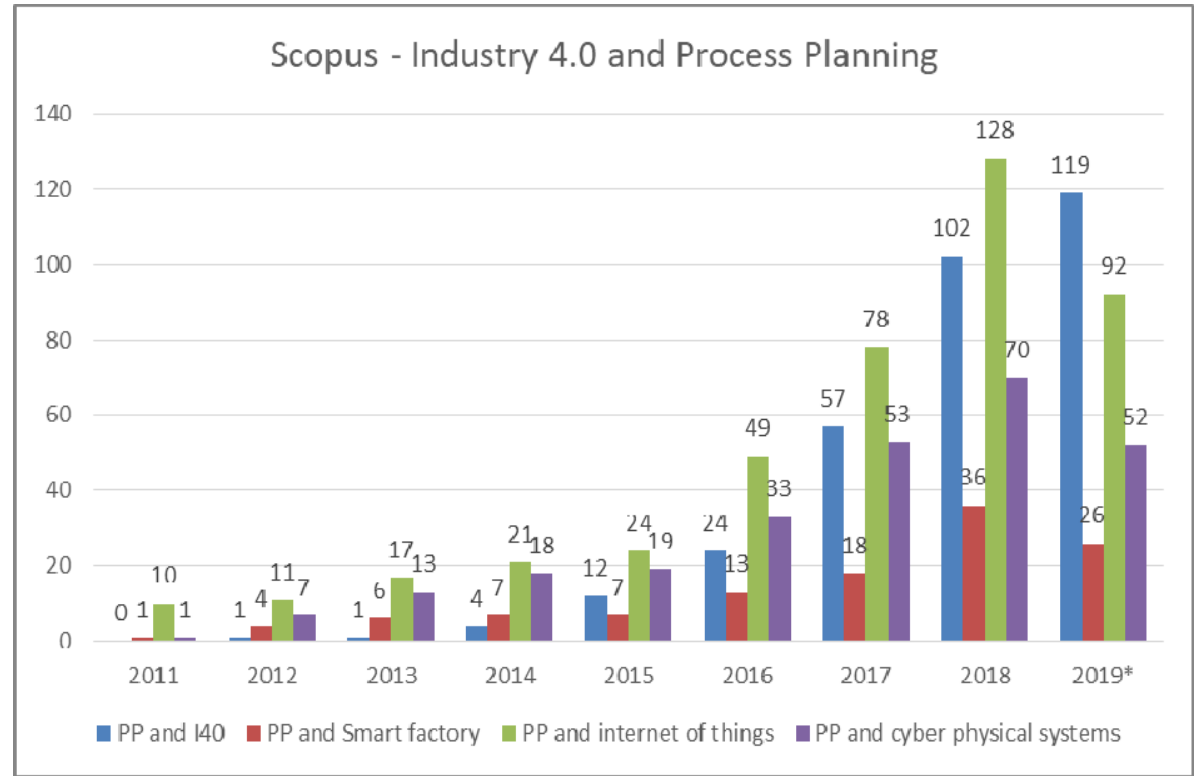

Fig. 9 Papers published from 2011 to 2019 in the Scopus database related to the Process Planning topic and Industry 4.0 and the related terms

In the Scopus database, the increase in the number of papers related to the Process Planning and Industry 4.0 topics is noted, but as in the WoS, this number generates only 1-5\% of the total number of papers published on the topic.

Further research links the topics of Industry 4.0 and the readiness factor calculation; the results are shown below.

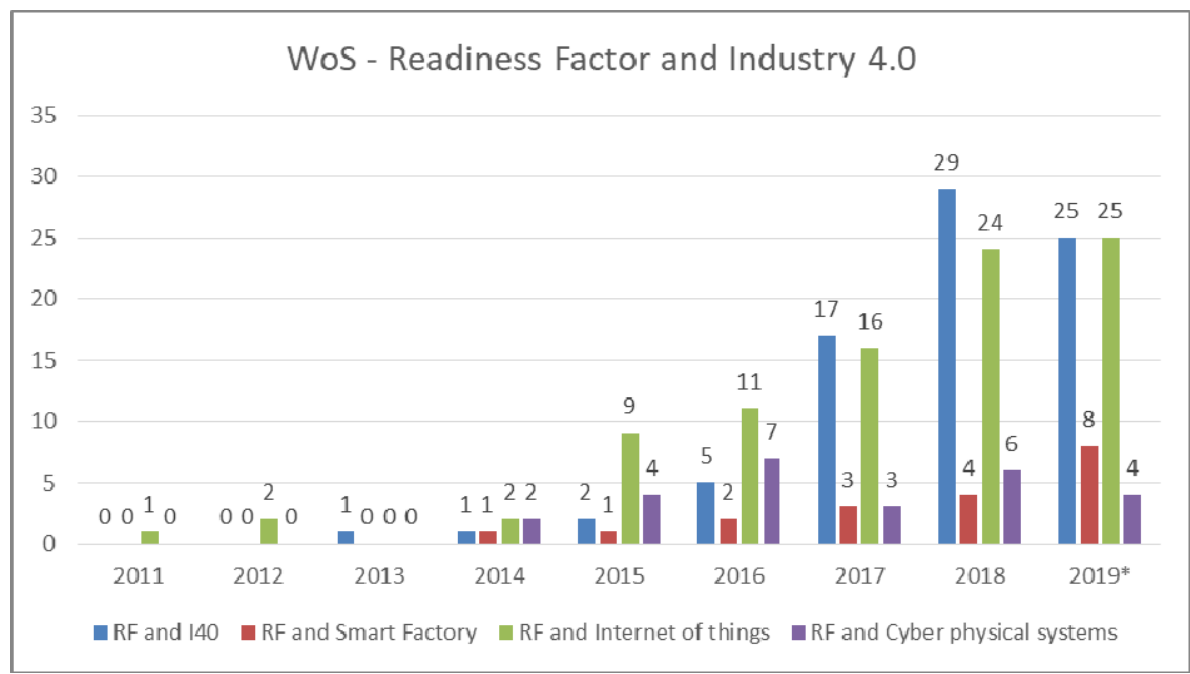

Fig. 10 Papers published from 2011 to 2019 in the Web of Science database related to the Readiness Factor topic and Industry 4.0 and the related terms

The research papers related to the readiness factor calculation for Industry 4.0 are published in even a smaller number, with only $1 \%$ or less from the entire Industry 4.0 field, which is the notification of the scientific gap currently present.

Based on the results, it can be concluded that Industry 4.0 is present as one of the trending and essential topics of the scientific field of industrial engineering today; it is an imperative for the companies all over the world to implement it.

In the first stage, before the implementation of Industry 4.0 concept, whose theoretical foundations have already been presented in the literature, the readiness factor should be 
calculated. Only a few percentages of the Industry 4.0 topic are devoted to the readiness factor calculation, which is mostly focused on the organizational system as a whole. Process planning in Industry 4.0 is presented in the literature even less, which reveals a scientific gap. A detailed review of the published studies in the field of Industry 4.0 readiness factor calculation will be presented in the following chapter.

\section{Literature review}

A theoretical approach to the concept of Industry 4.0 and its features, assessed by the statistical results from the databases given above and by previous research, has been presented, arousing a great interest of the experts. The approach is detailed enough to provide good knowledge of the concept. A framework for practical use has been established in the various types of industries and there are acknowledgments on the hardware, software, and organizational levels. Despite a good theoretical background, so far, there have been only few case studies on the use of the concept, most of them based only on the segments of the concept or on the concept of learning factories [8].

In the calculation of the readiness factor for Industry 4.0, there are commercial and scientific approaches, both different regarding their specific features and use in practice.

Table 1 shows the classification of all current findings from the field. The published studies have been divided into two major groups - Commercial approach and Scientific approach; both approaches will be described in detail, separately, in the following chapters. The difference between the commercial and the scientific approach is identified in order to acknowledge a possible difference between the studies reviewed by various experts from the field and published as relevant scientific publications (scientific approach) and the models and approaches developed in the companies whose goal can possibly be only personal profit, which may eventually result in a possible lack of the quality of the developed strategy (Commercial approach). Studies from the first group are divided into studies that deal with the self-assessment of the company and the readiness factor calculation based on the results of pools or structured interviews. In the second group, scientific papers are divided into two subgroups - the first one dealing with a general approach to the readiness factor calculation for the entire company, country or region and the second dealing with a detailed approach to the readiness factor calculation for a specific department in the company.

Table 1 Overview of methods for the calculation of readiness factor for Industry 4.0

\begin{tabular}{|c|c|c|c|}
\hline \multirow{12}{*}{$\begin{array}{l}\text { Industry } 4.0 \\
\text { readiness factor } \\
\text { calculation }\end{array}$} & \multirow{12}{*}{ Commercial } & \multirow{4}{*}{ Self-assessment } & Impuls-stiftung, 2018 [9] \\
\hline & & & EDB Singapore, 2018 [10] \\
\hline & & & KPMG Atlas, 2018 [11] \\
\hline & & & pwc, 2016 [12] \\
\hline & & \multirow{8}{*}{ Pool, structured interview } & $\begin{array}{l}\text { Readiness Assessment } \\
\text { (Warwick) [13] }\end{array}$ \\
\hline & & & I-Scoop, 2018. [14] \\
\hline & & & World Economic Forum [15] \\
\hline & & & Industry 4wrd, Malaysia [16] \\
\hline & & & McKinsey and Co, [17] \\
\hline & & & Boston Consulting Group, [18] \\
\hline & & & $\begin{array}{l}\text { Circumference Technology } \\
\text { Services, [19] }\end{array}$ \\
\hline & & & $\begin{array}{l}\text { Roland Berger Strategy } \\
\text { Consultants [20] }\end{array}$ \\
\hline
\end{tabular}




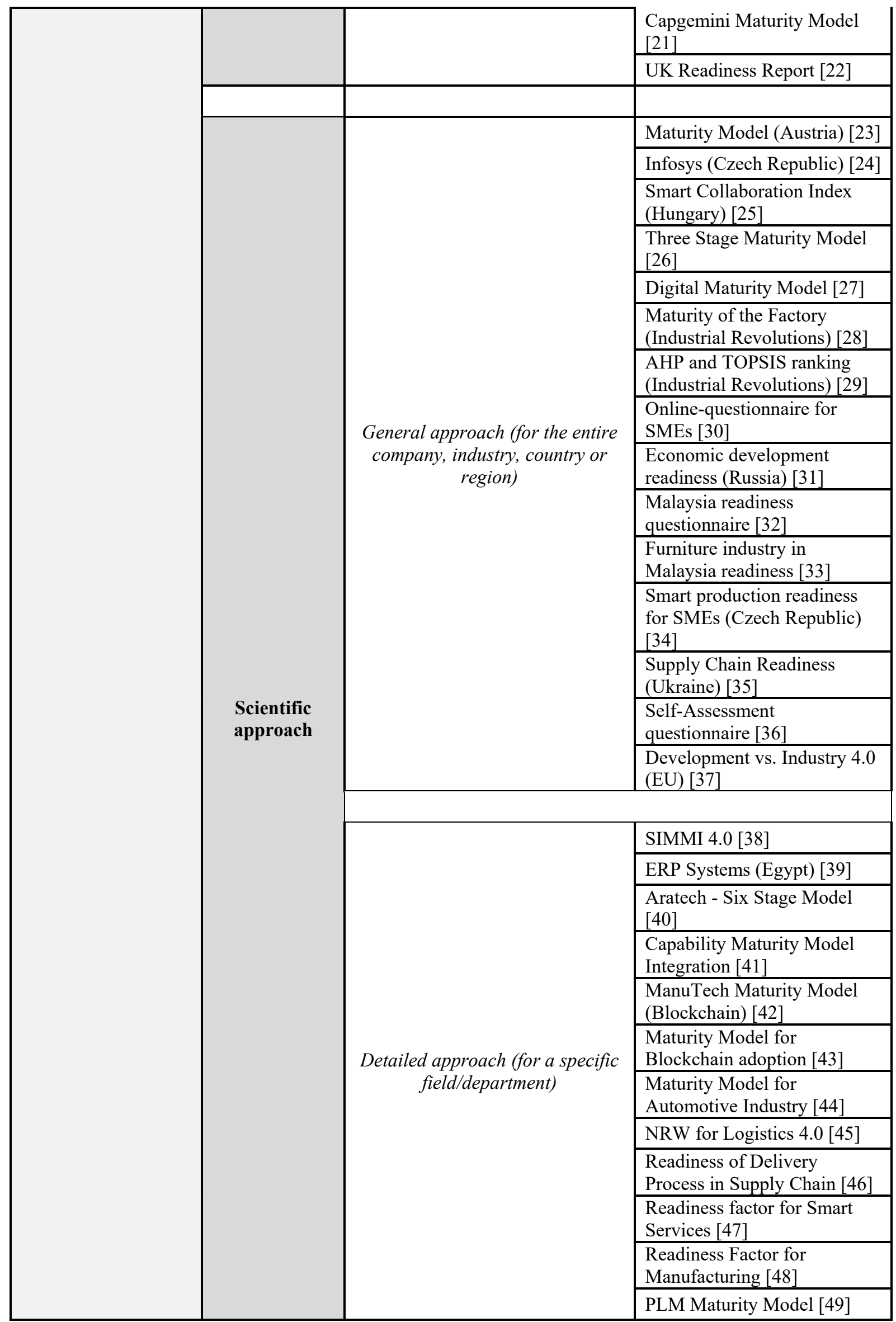




\subsection{Commercial approach}

The readiness factor, as a general overview of the current state in the company, has to plan and bring about the desired changes at lower costs and with the best effects in the future. So far, in the commercial versions of calculation methods, these requirements are roughly met, based on the pools, mostly by influential consulting firms.

IMPULS [9] from Germany defined Online Self-Check for Industry 4.0 readiness. This is an online form available to everyone interested. The goal is to check how well a subject is prepared for Industry 4.0 and to identify the places left for an improvement. They claim that the Readiness Model is a foundation for self-assessment and a comparison with other subjects from the field. It defines five (six) levels of readiness - Outsider, Beginner, Intermediate, Experienced, Expert and Top Performers. The first two are defined as Newcomers, the third as Learners and the last three are Leaders. The assessment is conducted by self-evaluation in the fields of Employees, Strategy and Organization, Smart Factory, Smart Operations, Smart Products and Data-driven Services with its subcategories. Within each category (dimension), several questions are posed in a typical online survey with automatic statistically defined results at the end and a comparison with other companies from the same field.

The University of Warwick in cooperation with Crimson\&Co and Pinsent Masons developed a readiness assessment tool with a "purpose to provide a simple and intuitive way for companies to start to assess their readiness and future ambition to harness the potential of the cyber-physical age" [13]. They claim that there are six core dimensions (with 37 subdimensions): Products and Services, Manufacturing and Operations, Strategy and Organization, Supply Chain, Business Model, and Legal Considerations. They classify the results into four categories - beginner, intermediate, experienced, and expert. The survey was conducted in 22 countries; respondents ( $74 \%$ of them were senior managers or executives) had to answer 53 questions. The results identified the current characteristics of the company based on the levels of readiness. Each sub-category is represented by a description matrix which shows the current position and the ambition for the future state of a single company.

The German Academy of Science and Engineering in collaboration with Infosys, Institute for Industrial Management (FIR) and RWTH Aachen University conducted a global study and formed an Industry 4.0 maturity model to explore the level of readiness within various industry types. The research "Industry 4.0: The state of the nation" helps the building of the Industry 4.0 Maturity Index which is focused on a detailed overview of the readiness. The survey conducted in over 400 manufacturing companies from 5 countries showed only the awareness of the concept and presented a general overview of the implementation in the digitalization process [14].

In 2018, at the World Economic Forum, the "Readiness for the Future of Production Report" was presented. The report set up an initiative for creating a sustainable future production that is solution-driven, human-centric, and inclusive. It also presented a benchmarking framework, a diagnostic tool and a data set to be used for determining the current level of readiness for the "future of production" of a country. The first analysis was made in India, Japan, Mexico, the Russian Federation and South Africa. Later on, more countries were included in the research. The Readiness Diagnostic Model Framework consists of two parts - Structure of Production and Diversity of Production. The first is divided into Complexity and Scale and the second into Technology \& Innovation, Human Capital, Global Trade \& Investment, Institutional Framework, Sustainable Resources, and Demand Environment. According to the results, the countries were divided into High-Potential, Leading, Nascent and Legacy categories. For the future of production, twelve key emerging technologies were acknowledged, among which are additive manufacturing, the use of advanced materials and nanomaterials, Blockchain and distributed ledger technology, and 
virtual and augmented realities. The readiness was evaluated on the scale from 1 to 10 with the own assessment weighting scheme. So far, this has been geographically the most detailed research [15].

The Economic Development Board claims that they have developed the "world's first Industry 4.0 tool to catalyse the transformation of industrial sectors during the 4th industrial revolution" [10]. This is presented as a diagnostic tool which helps to understand the I4.0 concept better in order to "deliver sustained value for their business". The main dimensions are Process, Technology, and Organization with its sub-dimensions. For each sub-dimension, an assessment matrix is formed for the company to evaluate the current processes within the organization.

In Malaysia, the Government [[15] was to support the Industry4wrd Readiness Assessment project in 2019 and 2020; the project was intended to "determine the state of readiness in the adoption of Industry 4.0 technologies", "identify the gaps and areas of improvement of I4.0 adoption as well as opportunities for productivity improvement and growth" and "develop feasible strategies and plans to perform outcome-based intervention projects". The "shift factors" have been identified and those are People, Process and Technology with their enablers which are Funding, Infrastructure, Regulations, Skills \& Talents, and Technology. The companies assessed in those categories will be labelled in one of the five categories defined: Conventional, Newcomer, Learner, Experienced, and Leader.

Smaller and more personalized projects, based on similar general criteria, are offered by many consulting companies as the standard consulting audit service. Similar audits, regional or state research were conducted by McKinsey and Co [16], Boston Consulting Group [17], KPMG Atlas [11], Circumference Technology Services [18], and pwc [12]; more from the similar field can be found in [19-21].

\subsection{Scientific approach}

Apart from the regular surveys, the scientific approach with more complex mathematical models is also frequently used within the field of readiness factor calculation for Industry 4.0.

One of the scientifically most relevant approaches is the maturity model [22] which is based on nine categories of the company: strategy, leadership, customers, products, operations, culture, people, governance, and technology. The data on these categories are collected within the company using a special questionnaire; the respondent has to fill in his answers about a single characteristics on the scale from 1 to 5 - fully implemented (5) or not at all (1). Subsequently, the data are interpreted using a special maturity mathematical model in which the output, i.e. the readiness factor, is a number that can be analysed for each category separately.

Another scientific research was conducted in the Czech Republic [23] where the main focus was on Industry 4.0 awareness, which is presented as the readiness. The questions in the questionnaire were based on the Infosys research mentioned previously. That is a basic theoretical approach in which the aim was only to get the results about the degree of awareness of the concept of Industry 4.0 in Czech companies.

The goal of SIMMI 4.0 (System Integration Maturity Model Industry 4.0) [38] is to assess the current readiness factor of a company in order to classify its IT system landscape based on digital requirements. SIMMI 4.0 consists of five stages; each stage describes one characteristic of digitalization and even enables the self-assessment. The readiness factor is a digitalization characteristic; for each stage, some activities are recommended as future steps to complete the digitalization process. 
Another study measured the readiness of the enterprise resource planning (ERP) systems for the factory of the future [39]. As a gathering tool, a number of interviews were conducted within companies in Egypt. The knowledge of the ERP systems and its use related to Industry 4.0 was investigated. Based on the answers provided by single respondents within the company, several challenges were noted.

The Industry 4.0 readiness factor of the cities was also calculated in Hungary in a case study. Michael Poerter's Diamond Model was used as the framework for a global competitiveness model, with the Smart Collaboration Index generated as a result [24].

The Three Stage Maturity Model [25] is a pilot approach which gives a digitalization action model and recognizes the opportunities to achieve the new concept within a company. The company is analysed through three stages in order to create individual vision for Industry 4.0. In the process, the information regarding Energy, Electronics, Digital Business and Advanced metal mechanic is analysed. In the first stage, Vision, an analysis of the capacity and resources is carried out together with the research into the general understanding of Industry 4.0. In the second stage, Roadmap, requirements for and the technology involved in Industry 4.0 are identified. In the final stage, Projects, the training capacity is defined along with risk management and future Industry 4.0 projects. In the end, the companies are grouped into one of the five stages - Initial, Managed, Defined, Transformed, Detailed BM-according to the appropriate maturity scale.

The aratech study of National Academy of Science and Engineering [40] conducted in Germany set the study of maturity index in which the transformation is characterized by six stages in the approach to the Industry 4.0 concept. The stages are: Computerization, Connectivity, Visibility, Transparency, Predictive Capacity, and Adaptability. These stages are preceded by several functional areas, i.e. Development, Production, Logistics, Services, and Marketing \& Sales. Six maturity stages are tested by Information systems, Resources, Organizational structure and Culture as the structural areas.

There is also an approach based on the Capability Maturity Model Integration (CMMI) [41] with different dimensions used to assess the areas of design and engineering, production management, quality management, maintenance management, and logistics management. The final result is the maturity level which describes the current practice in each dimension.

Similar maturity models were developed by Forrester (in dimensions of Culture, Technology, Organization, Insights) [49]. In addition, there are maturity models whose result is the level of readiness based on the level of industrial revolution characteristics [28], ManuTech Maturity Model [41], a maturity model developed for the block chain adoption [42], a maturity model in the automotive industry with the following dimensions: Cultivating digital people, Introducing agile processes, and Configuring modular technologies [43]. Apart from the traditional method based on the four industrial revolutions and the entire company, one method was developed specially for SMEs [29] which have a detailed organizational approach. The organizational level of economic development research was conducted in Russia [30], where the structuring and layering of the organization can lead to the Industry 4.0 implementation.

Maturity levels specialized for the field of Logistics 4.0 have been developed. One of them is the North Rhine-Westphalia (NRW) Industry 4.0 Maturity model [44] that covers the areas of business models, IT systems, quality management, process management, planning of production, control of production, logistics, and human-machine communications. That model is specialized for digitalized logistics systems while a similar maturity model was developed for the supply chain [45]. Supply chain readiness was tested on the case study of Ukrainian companies [34], where key drivers of the supply chain were identified first and then, based on the results, personal questionnaire was created and the results were tested on 
102 firms. The readiness factor was also the topic of the future framework of Smart Services [46].

For SMEs, an online pool self-assessment tool is designed; it enables the measurement of the readiness of the tools existing within the company and the analysis of the approach for the transformation period. The similar questionnaire-based maturity model was implemented in Malaysia for the general industry [47], while the special readiness questionnaire concerning the automation was distributed to furniture companies; the key driver analysis showed that those companies were not ready yet to accept the concept of Industry 4.0 [32]. Smart production and smart logistics self-assessment models were developed for SMEs in the Czech Republic [33].

Apart from the logistics, supply chain, and blockchain, a framework of the readiness factor calculation was developed for the manufacturing process [47]; it is based on the following dimensions: Strategies, Processes, Technology, Products, Services, and People.

One of the most advanced and most specific approaches to processes within a company is the Product Lifecycle Management Maturity Model [48] that adopted the ProKnow-C method with the analytical hierarchy process (AHP) method to verify the adherence of the product lifetime management (PLM) maturity models to Industry 4.0 criteria. However, only a framework for the testing of current maturity models is given. Within European Union, research was conducted [36] based on implementation of the single digital market strategy; the aim was to show the existence of a digital infrastructure combined with the analytical procedures for big data processing. The difference between the implementation of the Industry 4.0 concept and that of the natural development process was noted. In another study, [37], the available indexes and maturity models are grouped into individual layers of the meta-model for the readiness factor calculation within companies in the EU.

A complete overview of the readiness factor calculation methods currently available in the literature is shown in Table 2, with specifications about the fields of interest and short descriptions.

Table 2 General characteristics of the current Industry 4.0 readiness calculation methods published from 2011 to2019

\begin{tabular}{|c|c|c|}
\hline Method & $\begin{array}{l}\text { Field of } \\
\text { interest }\end{array}$ & Overview \\
\hline $\begin{array}{l}\text { Impuls-stiftung, } \\
2018[9]\end{array}$ & General & $\begin{array}{l}\text { Online self-assessment, brief overview of } 20 \text { assigned } \\
\text { criteria, divided into } 6 \text { groups, not personalized. }\end{array}$ \\
\hline $\begin{array}{l}\text { EDB Singapore, } \\
2018[10]\end{array}$ & General & $\begin{array}{l}\text { Criteria divided into three groups, with evaluation of the } \\
\text { Industry } 4.0 \text { characteristics within general companies, } \\
\text { although a good prioritization matrix with the influence of } \\
\text { revenue-cost profiles, KPI, and proximity to best-in-class is } \\
\text { included. }\end{array}$ \\
\hline $\begin{array}{c}\text { KPMG Atlas, } 2018 \\
{[11]}\end{array}$ & General & $\begin{array}{l}\text { Results in the overview of the current state on one of the six } \\
\text { dimensions, which are strategy, human, finance, system, and } \\
\text { network - without a detailed plan of change. }\end{array}$ \\
\hline pwc, 2016 [12] & General & $\begin{array}{l}\text { Online self-assessment in terms of } 4 \text { industrial revolutions; } \\
\text { the advantage is the possibility of benchmark. }\end{array}$ \\
\hline $\begin{array}{c}\text { Readiness } \\
\text { Assessment } \\
\text { (Warwick) [13] }\end{array}$ & $\begin{array}{l}\text { General, } 22 \\
\text { countries } \\
\text { included }\end{array}$ & $\begin{array}{l}\text { Technology adoption, with } 4 \text { readiness levels defined by the } \\
\text { criteria of product customization, digital features of product, } \\
\text { data-driven services, level of product data usage, and share } \\
\text { of revenue. No detailed transformation steps or exact } \\
\text { features to be changed are defined. }\end{array}$ \\
\hline
\end{tabular}




\begin{tabular}{|c|c|c|}
\hline I-Scoop, 2018 [14] & General & $\begin{array}{l}\text { Explores the general interest of the company in I } 40 \text { with a } \\
\text { subjective vision of their image in the future. }\end{array}$ \\
\hline $\begin{array}{l}\text { World Economic } \\
\text { Forum [15] }\end{array}$ & $\begin{array}{l}\text { General, } \\
\text { worldwide }\end{array}$ & $\begin{array}{l}\text { Key drivers of production are defined, with a detailed } \\
\text { description of certain technologies, more detailed than } \\
\text { others, but not personalized. }\end{array}$ \\
\hline $\begin{array}{l}\text { Industry 4wrd, } \\
\text { Malaysia [16] }\end{array}$ & $\begin{array}{l}\text { General, } \\
\text { Malaysia }\end{array}$ & $\begin{array}{l}\text { Making decision about three strategies and selection of one } \\
\text { that helps the company to achieve the desired goals; not } \\
\text { personalized and without exact steps defined. }\end{array}$ \\
\hline $\begin{array}{l}\text { McKinsey and Co, } \\
2018[17]\end{array}$ & $\begin{array}{l}\text { General, } \\
\text { manufacturing } \\
\text { industry }\end{array}$ & $\begin{array}{l}8 \text { dimensions, } 26 \text { criteria, no distinction between different } \\
\text { industry types. }\end{array}$ \\
\hline $\begin{array}{l}\text { Boston Consulting } \\
\text { Group, } 2017 \text { [18] }\end{array}$ & General & $\begin{array}{l}9 \text { dimensions, scanning and a brief overview with a focus on } \\
\text { general digital technologies. }\end{array}$ \\
\hline $\begin{array}{l}\text { Circumference } \\
\text { Technology } \\
\text { Services, } 2018[19]\end{array}$ & General & $\begin{array}{l}\text { Consultant approach with a focus on the implementation of } \\
\text { mobile apps. }\end{array}$ \\
\hline $\begin{array}{l}\text { Roland Berger } \\
\text { Strategy } \\
\text { Consultants [20] }\end{array}$ & $\begin{array}{l}\text { General, } \\
\text { Europe }\end{array}$ & Five point scale based on the financial contributors. \\
\hline $\begin{array}{l}\text { Capgemini Maturity } \\
\text { Model [21] }\end{array}$ & General & $\begin{array}{l}\text { Focus on certain industry types and their digital technology } \\
\text { use. }\end{array}$ \\
\hline $\begin{array}{l}\text { UK Readiness } \\
\text { Report [22] }\end{array}$ & General, UK & $\begin{array}{l}\text { Explores the understanding of the Industry } 4.0 \text { concept and } \\
\text { personal subjective predictions of the users. }\end{array}$ \\
\hline $\begin{array}{l}\text { Maturity Model } \\
\text { (Austria) [23] }\end{array}$ & General & $\begin{array}{l}\text { One of the most famous scientific approaches, mathematical } \\
\text { calculation by } 4+5 \text { dimensions with no focus on certain } \\
\text { industry types or further plan formulation. }\end{array}$ \\
\hline $\begin{array}{l}\text { Infosys (Czech } \\
\text { Republic) [24] }\end{array}$ & $\begin{array}{l}\text { General, Czech } \\
\text { Republic }\end{array}$ & Basic survey to analyse the knowledge of the concept. \\
\hline $\begin{array}{l}\text { Smart Collaboration } \\
\text { Index (Hungary) } \\
{[25]}\end{array}$ & $\begin{array}{l}\text { General, } \\
\text { Hungary }\end{array}$ & Smart Cities, Smart collaboration index developed. \\
\hline $\begin{array}{c}\text { Three Stage } \\
\text { Maturity Model } \\
{[26]}\end{array}$ & $\begin{array}{l}\text { General, } \\
\text { Austria }\end{array}$ & $\begin{array}{l}\text { Develops a three-step strategy to start the digitalization } \\
\text { period. }\end{array}$ \\
\hline $\begin{array}{l}\text { Digital Maturity } \\
\text { Model [27] }\end{array}$ & General & $\begin{array}{l}\text { Four dimensions with three key functional activities - } \\
\text { strategy, governance and operational excellence with a focus } \\
\text { on human character in the state of change. }\end{array}$ \\
\hline $\begin{array}{l}\text { Maturity of the } \\
\text { Factory (Industrial } \\
\text { Revolutions) [28] }\end{array}$ & $\begin{array}{l}\text { General, } \\
\text { manufacturing }\end{array}$ & $\begin{array}{l}\text { Focus on technology and production; results are obtained } \\
\text { based on } 8 \text { questions about the current use of certain } \\
\text { characteristics. }\end{array}$ \\
\hline $\begin{array}{l}\text { AHP and TOPSIS } \\
\text { ranking (Industrial } \\
\text { Revolutions) [29] }\end{array}$ & $\begin{array}{l}\text { General, } \\
\text { Croatia }\end{array}$ & $\begin{array}{l}\text { Use of decision support to rank the criteria using the AHP } \\
\text { and final readiness factor calculation together with TOPSIS. }\end{array}$ \\
\hline $\begin{array}{l}\text { Online- } \\
\text { questionnaire for } \\
\text { SMEs [30] }\end{array}$ & General, SMEs & $\begin{array}{l}\text { Definition of the readiness in six dimensions - strategy, } \\
\text { technology, production, products, and people; questionnaire- } \\
\text { based approach. }\end{array}$ \\
\hline
\end{tabular}

Economic

development

readiness (Russia)

General,

economy and

Focus on the controllability of economy and management [31]

finance

issues - barriers and risks. 


\begin{tabular}{|c|c|c|}
\hline $\begin{array}{l}\text { Malaysia readiness } \\
\text { questionnaire [32] }\end{array}$ & $\begin{array}{l}\text { General, } \\
\text { Malaysia }\end{array}$ & Use of IMPULS model in six dimensions. \\
\hline $\begin{array}{c}\text { Furniture industry } \\
\text { in Malaysia } \\
\text { readiness [33] }\end{array}$ & $\begin{array}{l}\text { General, } \\
\text { furniture } \\
\text { industry, } \\
\text { Malaysia }\end{array}$ & Level of automation, driving forces. \\
\hline $\begin{array}{l}\text { Smart production } \\
\text { readiness for SMEs } \\
\text { (Czech Republic) } \\
{[34]}\end{array}$ & $\begin{array}{l}\text { General, Czech } \\
\text { Republic, } \\
\text { SMEs } \\
\end{array}$ & Roadmap strategy. \\
\hline $\begin{array}{l}\text { Supply Chain } \\
\text { Readiness } \\
\text { (Ukraine) [35] } \\
\end{array}$ & $\begin{array}{l}\text { Supply Chain, } \\
\text { Ukraine }\end{array}$ & Drivers of change identification in Ukrainian enterprises. \\
\hline $\begin{array}{c}\text { Self-Assessment } \\
\text { questionnaire [36] }\end{array}$ & General & Self-assessment questionnaire definition. \\
\hline $\begin{array}{l}\text { Development vs. } \\
\text { Industry } 4.0(\mathrm{EU}) \\
{[37]}\end{array}$ & $\begin{array}{c}\text { General, } \\
\text { manufacturing, } \\
\text { EU }\end{array}$ & $\begin{array}{l}\text { Identification of existing digital infrastructure and handling } \\
\text { of big data. }\end{array}$ \\
\hline SIMMI 4.0 [38] & IT and software & $\begin{array}{l}\text { Possibility of self-assessment, stages of digitalization } \\
\text { explained. }\end{array}$ \\
\hline $\begin{array}{l}\text { ERP Systems } \\
\text { (Egypt) [39] }\end{array}$ & ERP & $\begin{array}{l}\text { Interview-based research on the current stage of ERP } \\
\text { systems and personal demands of industry users. }\end{array}$ \\
\hline $\begin{array}{l}\text { Aratech - Six Stage } \\
\text { Model [40] }\end{array}$ & General & Six stages of development defined. \\
\hline $\begin{array}{l}\text { Capability Maturity } \\
\text { Model Integration } \\
{[41]} \\
\end{array}$ & Manufacturing & $\begin{array}{l}\text { CMMI framework in } 5 \text { key manufacturing areas - design and } \\
\text { engineering, production management, quality management, } \\
\text { maintenance management, and logistics management. }\end{array}$ \\
\hline $\begin{array}{l}\text { ManuTech Maturity } \\
\text { Model (Blockchain) } \\
\text { [42] }\end{array}$ & $\begin{array}{l}\text { Manufacturing } \\
\text { Poland }\end{array}$ & $\begin{array}{l}8 \text { dimensions of the manufacturing industry as the main } \\
\text { focus. }\end{array}$ \\
\hline $\begin{array}{l}\text { Maturity Model for } \\
\text { Blockchain } \\
\text { adoption [43] }\end{array}$ & Blockchain & Development of the model for blockchain adoption. \\
\hline $\begin{array}{l}\text { Maturity Model for } \\
\text { Automotive } \\
\text { Industry [44] }\end{array}$ & $\begin{array}{l}\text { Automotive } \\
\text { industry }\end{array}$ & $\begin{array}{l}\text { Challenges by the experience of five automotive companies } \\
\text { - four levels of development. }\end{array}$ \\
\hline $\begin{array}{l}\text { NRW for Logistics } \\
4.0[45]\end{array}$ & Logistics & Rough outlines of Logistics 4.0 maturity model. \\
\hline $\begin{array}{l}\text { Readiness of } \\
\text { Delivery Process in } \\
\text { Supply Chain [46] }\end{array}$ & $\begin{array}{c}\text { Supply chain - } \\
\text { Delivery } \\
\text { process } \\
\end{array}$ & $\begin{array}{l}\text { Towards delivery logistics excellence and guidance on the } \\
\text { development; no validation available. }\end{array}$ \\
\hline $\begin{array}{l}\text { Readiness factor for } \\
\text { Smart Services [47] }\end{array}$ & $\begin{array}{l}\text { Smart Services, } \\
\text { Germany }\end{array}$ & $\begin{array}{l}\text { Sub-categories in technology management, financial } \\
\text { resources, and corporate culture. }\end{array}$ \\
\hline $\begin{array}{c}\text { Readiness Factor } \\
\text { for Manufacturing } \\
{[48]}\end{array}$ & Manufacturing & $\begin{array}{l}\text { Roadmap definition following } 5 \text { dimensions: Strategy, } \\
\text { Processes, Technologies, Products \& Services, and People. }\end{array}$ \\
\hline $\begin{array}{l}\text { PLM Maturity } \\
\text { Model [49] }\end{array}$ & PLM & $\begin{array}{l}\text { Use of ProKnow-C and AHP method for the maturity } \\
\text { model. }\end{array}$ \\
\hline
\end{tabular}




\subsection{Gaps in the current findings}

Most of the maturity models/readiness factor calculation methods were presented in public in 2017 and 2018 and most of them are focused on acknowledging the current situation within the industry on the state level or as a global comparison (EU), as shown in Figure 11. The commercial versions of the methods enable the audit process of a single company, but at a very general level. The audit process is based on the questionnaire whose results are evaluated using the most common statistical methods to get the average grade of readiness within the company. Its structure is based on the characteristics of the four industrial revolutions as such, with no detailed scanning of the parts of an organization or the departments of manufacturing companies.

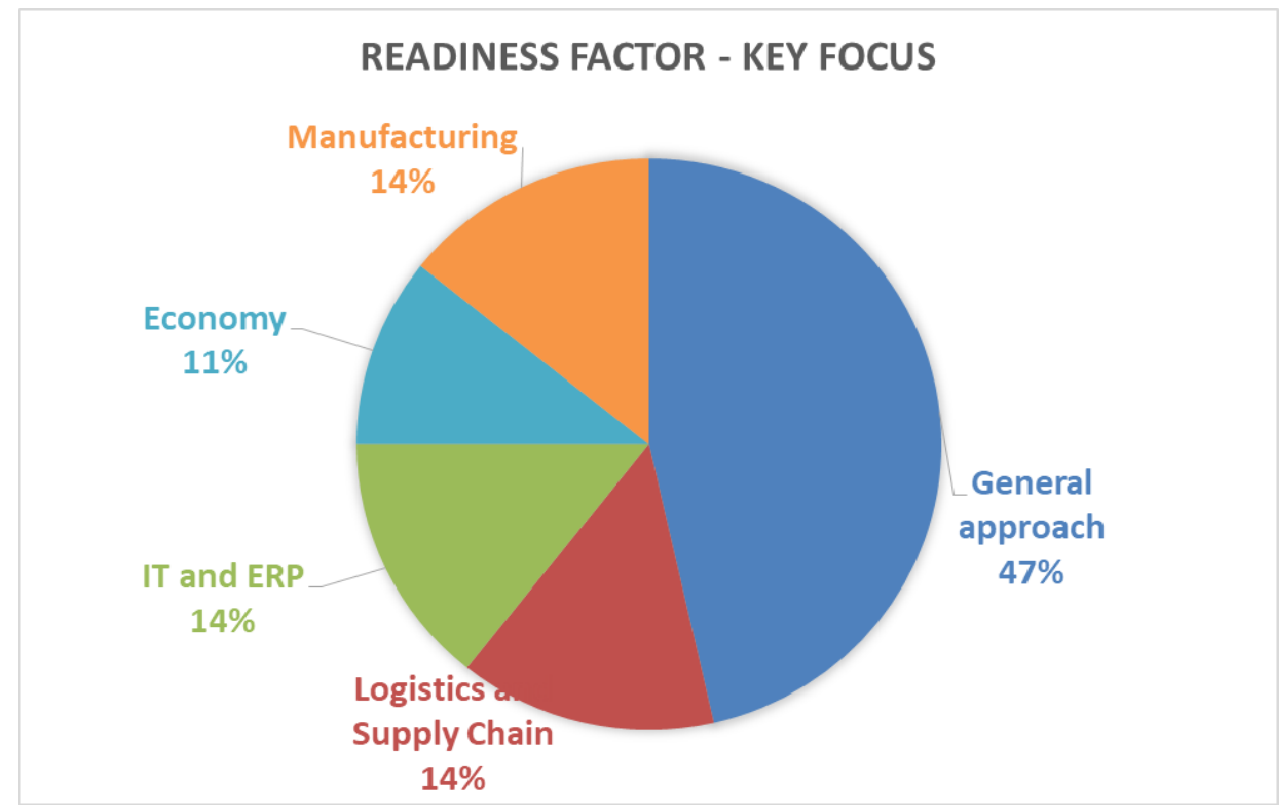

Fig. 11 Distribution of fields on which the Industry 4.0 readiness calculation methods published from 2011 to 2019 are focused

Figure 11 shows the distribution of the readiness factor calculation methods developed based on the specific field of interest. The majority of the published methods are based on a general approach, which is the scanning of the company as a whole. There are also methods based on the field of logistics, economy, manufacturing and IT, but none on the process planning as a specific and single field (although there have been certain digitization solutions, but only as part of the digitization of the complete manufacturing process $[40,41,47])$. The Fraunhofer approach is closest to the process planning readiness check; its principle is the online self-assessment of the manufacturing company by nine dimensions (IT-supported production planning, real-time production control system, IT system for supply chain management, IT system for product lifecycle management, IT-based control of internal logistics, mobile/wireless programming of machines, safe human-machine cooperation, mobile/wireless access to work instructions, and scope of investment for machines and systems). The process planning is incorporated in the first dimension (IT-supported production planning), as an essential part which is directly connected to the scheduling and manufacturing optimization. The description of the direct inner and outer factors influencing the process planning as such is not detailed to a sufficient level to enable the creation of the automatized process plan as the final product [50].

Regarding the readiness assessment via questionnaires, there are several approaches in which questions are also based on the basic theoretical framework of the Industry 4.0 concept. These approaches are mostly universal, intended for both service and manufacturing 
companies, with no credits for different industry fields. There are certain readiness factor calculation models developed for the departments like supply chain, enterprise resource planning (ERP) systems and human resources. Readiness of process planning departments has not yet been discussed in the literature, which has been recognized as a scientific gap, a field which should be discussed and developed in the future.

A disadvantage of the current readiness factor calculation methods is the general approach, which does not include a detailed overview of the processes for various industry types which are important for the transformation of manufacturing companies, especially for SMEs.

Another gap in the current scientific achievements is in the fact of raising the awareness of both importance and risks that the digitalization period brings to SMEs. It requires high investments and sometimes even radical changes that are not easy to identify. Moreover, in order to result in future benefits, the changes have to be provided carefully and have to be personalized, with a detailed plan for each dimension defined, for which the general approach presented is not an adequate method.

Apart from the differences between various industry types, there are uneven digitalization levels needed within each department in a single company. The transformation of the manufacturing, logistics, and process planning departments is for sure more complex than the transformation of the human resources or the accounting department. Because of different hardware and software requirements for achieving a certain level of digitalization, the readiness factor could not be defined generally for the entire organization, but for the stand-alone departments with the intention of establishing their digital connection. Before the readiness factor calculation, an ideal model of each department should be defined, with a personalized approach to every company and their needs.

The process planning department, which is a step between design and manufacturing, is a point where technological processes are defined, and tools and machines with their working regimes and operation sequences are selected. The readiness factor of the process planning department model has not yet been presented; in order to define it, a new model, presented in the following chapter, had to be developed.

\section{Calculation of readiness factor for process planning}

Based on The readiness factor calculation framework with its main dimensions of focus for process planning is defined based on the current findings about the Industry 4.0 structure and its main elements presented in the previous chapters, and also on the previous research conducted by the authors.

The ideal model of process planning according to the Industry 4.0 concept is an upgrade to CAPP systems, with the use of the predictive analytics based on the data collected from each part of the supply chain - construction, manufacturing, logistics, procurement, sale and the final users. It also consists of a database with previously generated process plans which enable the automatic creation of optimal new process plans [6].

This model defines the ideal state of process planning in the Industry 4.0 concept and supports the creation of the criteria (dimensions, as previously noticed in the literature) required for the evaluation of the current process.

The criteria must refer to every part of the department - hardware, software and organization/human work levels. The current state of the process planning department has to be evaluated by comparing it with the ideal state, using different priorities for each criterion. 
Based on the evaluation of defined criteria, the readiness factor should be calculated using the multi-criteria decision support methods, which can also be automatized and can generate optimum results. These methods are the Analytic Hierarchy Process (AHP), ELECTRE, and PROMETHEE, which are already implemented in the software that allows the formation of expert groups within the company itself. In the end, the cost/benefit analysis should be provided for the correct investment plan definition, which is the most challenging step, especially for SMEs.

To make the calculation as accurate as possible, the criteria should be established according to the demands of a particular industry, department, or a single user. According to the ideal structure given in the literature and the gaps in the current readiness factor calculation methods presented and examined in the previous chapter, the main criteria that should be evaluated for the calculation of the readiness factor in process planning are developed. These criteria, shown in Figure 12, are the aspects which should be compared with the state of the ideal model. Based on the results, the strategy and investment plans of the transformation and digitalization of the department should be developed.

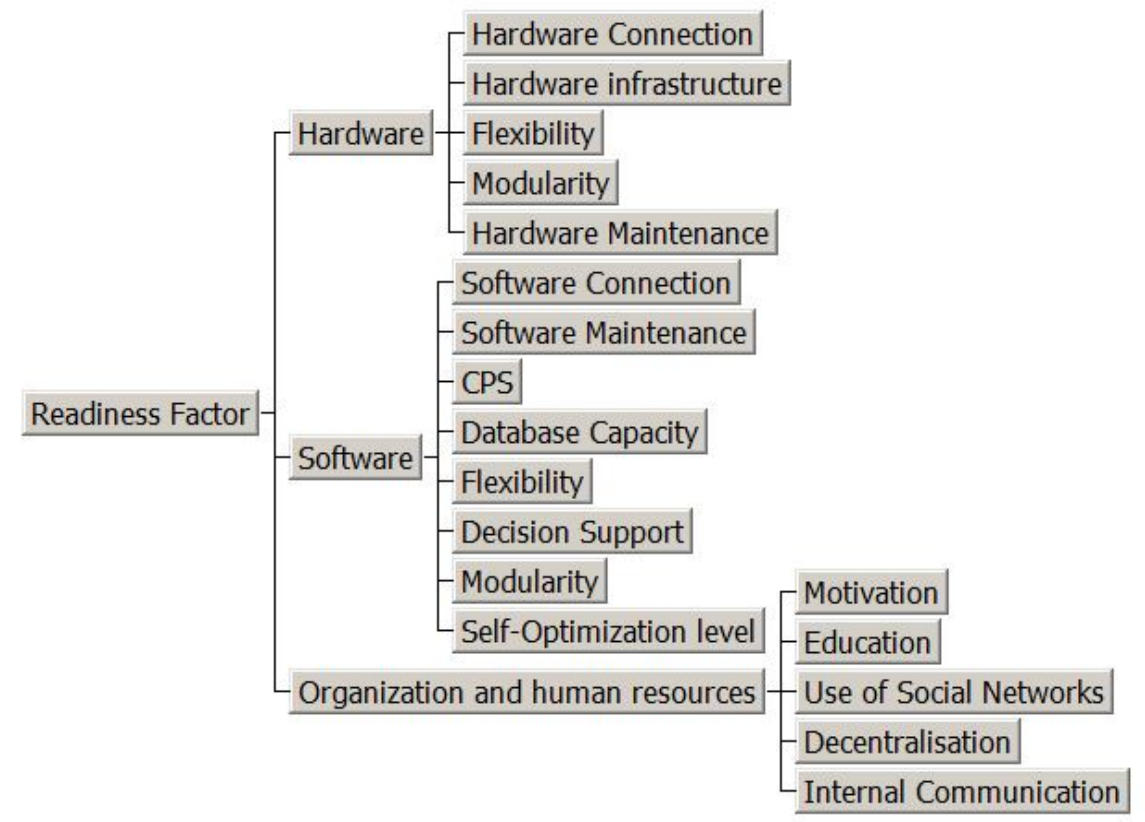

Fig. 12 The structure of new criteria (dimensions) for the calculation of readiness factor focused on process planning

While the main focus in the previous research was on the evaluation of the use of the most recent technologies such as cloud computing and big data analytics, the new criteria are developed from the base on which the new digital technologies and principles are being built. The idea is to evaluate the basic infrastructure which is needed to generate parts of the new digitalized work process. Since most of the companies still have not fully implemented the new concept, most of the criteria are formed to evaluate the beginner stage of the concept, with a few that are directly connected with new technologies (Cyber Physical Systems, Decision Support, and Social Networks). With this type of criterion structure, a clearer and simpler overview of the current situation can be given in order to define the strategic plan of digitalization step by step.

The criteria are divided into three main groups - Hardware, Software and Organization and human resources. This covers every aspect of the working area of the process planner, which is now actively connected with other parts of the supply chain in the real time for the case of continuous work optimization and improvement. 
Hardware group includes the evaluation of the connection between the current hardware, the required quantity of hardware, the functionality (Hardware Infrastructure), and the flexibility of the present hardware, its modularity and the present maintenance model that ensures proper functionality.

Software group includes the connection between different software being used, both in the process planning department and in others, with its interoperability included. The maintenance of software must also be evaluated because of the importance of its constant functionality and data protection regarding the big threat of the cybercriminal, which is among the biggest threats and obstacles to the Industry 4.0 development in general. That is why the cybercriminal has become a burning issue in the recent scientific research. The presence of the cyber-physical systems is also to be evaluated with the focus on the humanmachine and machine-machine communication and collaboration levels.

Organization and human resources group includes the important human factor, in which workers should be ready and able to accept the change; for that purpose, their current motivation and education levels should be evaluated. The internal communication within a department and with other departments is made through social networks. As Industry 4.0 concept demands the horizontal and the vertical integration, the level of decentralization should also be evaluated.

\section{Conclusion}

Today, the Industry 4.0 concept is one of the main trends and goals in both manufacturing and service companies. It is implemented after the transitional digitalization period which demands a radical transformation that can sometimes require very high investments. This is very challenging, especially for SMEs, but the need for transformation is essential for maintaining the competitiveness level on the market.

That is why the readiness factor calculation before the first stage of digitalization is hugely important. The data collected from the largest scientific databases shows an increase in the interest for the Industry 4.0 topic and a continuous development of the process planning field. The number of studies and projects dealing with the readiness for Industry 4.0 has also increased over the years, but there are certain gaps that have been noted in this paper. The calculation methods are mostly based on the online questionnaires or interviews as the data collecting tool which is standardized for various industry types. Very rarely, advanced mathematical methods are used with the help of the decision support systems which is found to be a very useful tool for the readiness factor calculation. Most of the studies deal with the readiness of the company as a whole, but that does not give detailed results suitable for creating an accurate strategic and investment plan and avoiding potential loss in the future. The process planning department, as well as the others, has to be transformed and digitalized, but no specific readiness factor calculation method for this field has been presented. That is why, the essential criteria (dimensions) have been developed and grouped into three main groups - Hardware, Software and Organization and Human Resources. They are focused on the new technologies, which allow a possibility of identifying the flaws in the current system and an accurate evaluation, compared to the ideal model.

For future research, an exact mathematical method for the evaluation of criteria has to be defined, while the readiness factor should be calculated using decision support systems. In addition, the automatization of this process (readiness factor calculation for process planning) is one of the challenges to be overcome with a personalized approach to each customer/company. 


\section{REFERENCES}

[1] Lasi, H., Fettke, P., Kemper, H., Feld, T., \& Hoffmann, M.: Industry 4.0, Business \& Information Systems Engineering, 2014, 6(4), 239-242 http://doi.10.1007/s12599-014-0334-4

[2] Prause, G.: Sustainable business models and structures for industry 4.0, Journal of Security and Sustainbility Issues, 2015. 5(2) https://doi.org/10.9770/jssi.2015.5.2(3)

[3] Zhong, Y., Chen, Z., Zhou, Z., Hu, H.: Uncertainty Analysis and Resource Allocation in Construction Project Management, Engineering Management Journal, 2018, 30(4), 293-305 https://doi.org/10.1080/10429247.2018.1492269

[4] Jaradat, R., et al.: Assessment of Workforce Systems Preferences/Skills Based on Employment Domain, Engineering Management Journal, 2018, 31(4), 2377-0643 https://doi.org/10.1080/10429247.2019.1672407

[5] Xu, X.: Machine Tool 4.0 fot the new era of manufacturing, The International Journal of Advanced Manufacturing Technology, 2017, 92(5-8), 1893-1900 https://doi.org/10.1007/s00170-017-0300-7

[6] Trstenjak, M., Cosic, P.:. Process Planning in Industry 4.0 Environment, Procedia Manufacturing, 2017, 11, 1744-1750 https://doi.org/10.1016/j.promfg.2017.07.303

[7] Bartodziej, C.: The Concept Industry 4.0, IN: The Concept Industry 4.0, Bestmasters, Springer Gabler, Wiesbaden, 2016.

[8] Trstenjak, M.: Challenges of Human Resources Management with implementation of Industry 4.0, Proceedings of IOTSM2018 Scientific Conference, 2018, London, UK

[9] Impuls-stiftung: Industrie 4.0-Readiness, 2018

[10] Economic Development Board Singapore: The Singapore Smart Industry Readiness Index, 2018

[11] KPMG Atlas: Industrie 4.0 Readiness Assessment, 2018

[12] pwc: Industry 4.0 - Enabling Digital Operations, 2016

[13] Godsell, J., Agca, O., Gibson, J., Ignatius, J., Daview, C.W., Xu, O.: An Industry 4 readiness assessment tool, International Institute for Product and Service Innovation, The University of Warwick, 2018

[14] I-Scoop: Gaps in Industry 4.0 readiness contribute to Industrie 4.0 Maturity Index, 2018

[15] Industry 4WRD: National Policy on Industry 4.0, Ministry of International Trade and Industry, Malaysia, 2018

[16] Martin, c. et al: Readiness for the Future of Production Report, 2018

[17] McKinsey and Company: Industry 4.0 at McKinsey's model factories, 2018

[18] Boston Consulting Group: Embracing Industry 4.0 and Rediscovering Growth, 2018

[19] Circumference Technology Service: Transitioning To An Industry 4.0 Capable Factory: An Essential Step To Future-Proofing Your Manufacturing Operations, 2018

[20] Blanchet, M., Rinn, T., von Thaden, G. de Thieulloy, G.: Industry 4.0: The new industrial revolution How Europe will succeed, Roland Berger Strategy Consultants, 2014, GMBH, Munich, Germany.

[21] Capgemini: Industry 4.0 Maturity Model - Mirroring today to sprint into the future, 2018

[22] The Manufacturer: Industry 4.0 UK Readiness Report, 2018

[23] Schumaher, A., Erol, S. \& Sihn, W.: A Maturity Model for Assessing Industry 4.0 Readiness and Maturity of Manufacturing Enterprises, Procedia CIRP, 2016, 52, 161-166 https://doi.org/10.1016/j.procir.2016.07.040

[24] Basl, Josef \& Doucek, Petr.: A Metamodel for Evaluating Enterprise Readiness in the Context of Industry 4.0, Information, 2019, 10(89) https://doi.org/10.3390/info10030089

[25] Nick, G. \& Pongracz, F.: How to measure industry 4.0 readiness of cities. Scientific proceedings of International scientific conference Industry 4.0, 2016, 64-68, Borovets, Bulgaria

[26] Ganzarain, J., \& Errasti, N.: Three stage maturity model in SME's toward industry 4.0, Journal of Industrial Engineering and Management, 2016, 9(5), 1119-1128 https://doi.org/10.3926/jiem.2073

[27] Gill, M. \& VanBoskirk, S.: The Digital Maturity Model, Forrester Research, Inc. 2016, Cambridge, MA, USA.

[28] Koska, A., Göksu, N., Mehri B. \& Fettahlioglu, H.S.: Measuring the Maturity of a Factory for Industry 4.0, International Journal of Academic Research in Business and Social Sciences, 2017, 7(7), 52-60 https://doi.org/10.6007/ijarbss/v7-i7/3077 
[29] Babić, Z., Veža, I., \& Pavić, I.: Ranking of enterprises with regard to industrial maturity level using AHP and TOPSIS, ISAHP 2016 https://doi.org/10.13033/isahp.y2016.097

[30] Trotta, D. \& Garengo P.: Assessing Industry 4.0 Maturity: An Essential Scale for SMEs, Proceedings of 8th International Conference on Industrial Technology and Management (ICITM), 2019, Cambridge, United Kingdom, 69-74 https://doi.org/10.1109/icitm.2019.8710716

[31] Popkova E.G., Egorova E.N., Popova E., Pozdnyakova U.A.: The Model of State Management of Economy on the Basis of the Internet of Things, Ubiquitous Computing and the Internet of Things: Prerequisites for the Development of ICT, Studies in Computational Intelligence, 826, Springer, 2019 https://doi.org/10.1007/978-3-030-13397-9_116

[32] Hamidi S.R., Aziz A.A., Shuhidan S.M., Aziz A.A., Mokhsin M.: SMEs Maturity Model Assessment of IR4.0 Digital Transformation, Proceedings of the 7th International Conference on Kansei Engineering and Emotion Research, Advances in Intelligent Systems and Computing, 2018, 739 Springer, Singapore https://doi.org/10.1007/978-981-10-8612-0_75

[33] Ratnasingam, J., Ab Latib, H., Yi, L., Liat, L., Khoo, A.: Extent of automation and the readiness for industry 4.0 among Malaysian furniture manufacturers. BioResources, 2019, 14(3), 7095-7110

[34] Modrak V., Soltysova Z., Poklemba R.: Mapping Requirements and Roadmap Definition for Introducing I 4.0 in SME Environment. Advances in Manufacturing Engineering and Materials. Lecture Notes in Mechanical Engineering, 2019, Springer https://doi.org/10.1007/978-3-319-99353-9_20

[35] Krykavskyy, Y., Pokhylchenko, O., \& Hayvanovych, N.: Supply chain development drivers in industry 4.0 in Ukrainian enterprises, Oeconomia Copernicana, 2019, 10(2), 273-290 https://doi.org/10.24136/oc.2019.014

[36] Brozzi R., D’Amico R.D., Pasetti Monizza G., Marcher C., Riedl M., Matt , D.: Design of Selfassessment Tools to Measure Industry 4.0 Readiness, A Methodological Approach for Craftsmanship SMEs, Product Lifecycle Management to Support Industry 4.0, PLM 2018, IFIP Advances in Information and Communication Technology, 2018, 540. Springer https://doi.org/10.1007/978-3-030-01614-2_52

[37] Castelo-Branco, I., Cruz-Jesus, F., \& Oliveira, T.: Assessing Industry 4.0 readiness in manufacturing: Evidence for the European Union, Computers in Industry, 2019, 107, 22-32 https://doi.org/10.1016/j.compind.2019.01.007

[38] Leyh, C., Schäffer, T., Bley, K., Bay, L.: The Application of the Maturity Model SIMMI 4.0 in Selected Enterprises, Proceedings of 23rd Americas Conference on Information Systems, AMCIS 2017, Boston, MA, USA

[39] Haddara, M., Elragal, A.: The Readiness of ERP Systems for the Factory of the Future, Procedia Computer Science, 2015, 74, 721-728 https://doi.org/10.1016/j.procs.2015.08.598

[40] Schuh, G., Anderl, R., Guausemeier, J., ten Hompel, M., Wahlster, W.: Industrie 4.0 Maturity Index: Managing the Digital Transformation of Companies (aratech STUDY). Herbert Utz Verlag, Munich, 2017

[41] De Carolis, A., Macchi, M., Negri, E., Terzi, S.: A Maturity Model for Assessing the Digital Readiness of Manufacturing Companies, Proceedings of IFIP International Conference on Advances in Production Management Systems, Springer International Publishing, 2017, 13-20 https://doi.org/10.1007/978-3-319-66923-6_2

[42] Gracel, J., Łebkowski, P.: The Concept of Industry 4.0 Related Manufacturing Technology Maturity Model (Manutech Maturity Model, MTMM), Decision Making in Manufacturing and Services, 2019, 12 , 17-31 https://doi.org/10.7494/dmms.2018.12.1-2.17

[43] Wang, H., Chen, K., Xu, D.: A maturity model for blockchain adoption, Financial Innovation, 2016, 2(12) https://doi.org/10.1186/s40854-016-0031-z

[44] Sjödin, D.R., Parida, V., Leksell, M., Petrovic, A.: Smart Factory Implementation and Process Innovation, Research-Technology Management, 2018, 61(5), 22-31 https://doi.org/10.1080/08956308.2018.1471277

[45] Gajšek, B., Sternad, M., Lerher, T.: Maturity Levels For Logistics 4.0 Based On Nrw'S Industry 4.0 Maturity Model, Proceedings of 18th international scientific conference Business Logistics in Modern Management, Osijek, Croatia, 2018, 695-708

[46] Asdecker, B., Felch, V.: Development of an Industry 4.0 maturity model for the delivery process in supply chains, Journal of Modelling in Management, 2018, 13(4), 840-883 https://doi.org/10.1108/JM2-03-2018-0042 
[47] Kaltenbach, F., Marber, P., Gosemann, C., Bölts, T., Kühn, A.: Smart Services Maturity Level in Germany, Proceedings of IEEE International Conference on Engineering, Technology and Innovation (ICE/ITMC), Stuttgart, 2018 https://doi.org/10.1109/ICE.2018.8436329

[48] Canetta, L., Barni, A., Montini, E.: Development of a Digitalization Maturity Model for the Manufacturing Sector, Proceedings of 2018 IEEE International Conference on Engineering, Technology and Innovation (ICE/ITMC) Stuttgart, 2018 https://doi.org/10.1109/ice.2018.8436292

[49] dos Santos K.C.P., de Freitas Rocha Loures E., Junior O.C., Santos E.A.P.: Product Lifecycle Management Maturity Models in Industry 4.0, Product Lifecycle Management to Support Industry 4.0. PLM 2018, IFIP Advances in Information and Communication Technology, 2018, 540, Springer https://doi.org/10.1007/978-3-030-01614-2_60

[50] Fraunhofer ISI: Industriebenchmarking: Readiness I 4.0 -http://www.industriebenchmarking.eu/readiness (last accessed 2.4.2020.)

Submitted: $\quad 20.2 .2020$

Accepted: $\quad 06.5 .2020$

\author{
Maja Trstenjak* \\ Tihomir Opetuk \\ University of Zagreb \\ Faculty of mechanical engineering and \\ naval architecture \\ Ivana Lučića 5 \\ 10000 Zagreb \\ Croatia \\ maja.trstenjak@fsb.hr
}

